\title{
The Silent Contributors: Domestic and Traditional Tenun Ikat Women in Tanimbar, Mollucas
}

\author{
Aveanty Miagina \\ aveanty.miagina@gmail.com \\ FISHUM-Manajemen, Universitas Halmahera
}

\begin{abstract}
Tenun ikat women in Tanimbar, Mollucas, have provided significant contribution to their society, especially in regard to their indigenous heritage, as well as to their own families. On the other hand, their weaving activities (menenun) are considered as supporting the continuity of their inherited customs. And on the other hand, they are also the housewife who play important role in taking care of their family's needs. The different weaving motifs done by Tenun Ikat women somehow related to the exploration of their identity as a women within the patriachal system of the Tanimbar's society. This study argues that some of these weaving motifs are related to thier spirit of empowerment. Playing the role as traditional women, they have built their positive indentity towards their family, relatives and their surroundings. More to that, the 'aoutonomous energy' as being portrayed in their roles as traditional women are seen through different weaving motifs of Tenun Ikat Tanimbar. Further, this study aims to underline that even though the Tenun Ikat women are attached to thier traditional roles as woman, but their self-consciousness and understanding go their true identity as a free and independent woman.
\end{abstract}

Keywords: tenun ikat, tenun ikat's motifs, weaving, autonomous energy, Tanimbar

\section{Introduction}

Multitasking, or the multi-functionality of the variations of women's role as the prior contributors in many aspects of life. Aside of their role as a wife, mother, or sister in their family, women are also a competitor for men [6]. This condition has demanded them to reveal their skill and abilities to become multitasking [9][19]. Weaving, is one of the domestic activities which are dominated by women. A study conducted by Hermayanti \& Erawati in Nagarai, describes the double roles of weaving women, either as a housewife or a breadwinner who has an important contribution to their life [8].

In the past, women in Athens who had the weaving and spinning skills were much honored [19]. Moreover, these activities were carried out as part of women's domestic activities which were described as the means to conserve the peaceful married life, as well a specifying the sense of comfort [19]. These study clearly suggests the importance of women's responsibility which was described in to their domestic textile creation as their primary task of activity. For that reason, their weaving ability can be considered as the noble activity.

Women;s role in the textile-making can be traced back to the Neolithic period [19], of which the perceptions on doing the typical men's job were different. Men are usually identified of doing the heavy jobs, while for the women are usually identified with raising the children, cooking, and indeed, weaving. However, the women were disagreed with these matter of identifications. For them, they were also able to do men's type job, especially as the breadwinner of the family without abandoning their main role as the housewife. Meanwhile in the present day, weaving still become the activity predominantly done by women. This can be argue to the fact that weaving required thoroughness, patience and perseverance, the skill-sets which are better described and suitable for women than for men.

Weaving has a close meaning with the aspect of social, economic, aesthetics and customs of one's community. Weaving the fabrics can be used as a symbol of strengthening the social relation [14]. It is not only functioned as a clothes, but it has developed as the complementary element in various traditional ceremonies, as seen in the birth ceremony, funeral of the death, house building, and also wedding ceremonies. After Batik was acknowledged by UNESCO as the Intangible Cultral Heritage in 2009, there havae been a significant increase of public interests in Indonesia for the weaving clothes as well. This, the weaving clothes are no longer limited to the formal traditional ceremonials, but have also emerged into the daily fashion. In Tanimbar island, it has become mandatory to all of the civil servants, as well as students of all levels of education, to incorporate the traditional weaving clothes as part of their uniforms. This strategy was intended to further conserve the Tanimbar's weaving as the high-valued symbol in the society. 
The cultural values that can be found in the weaving are beautiful and artistic. The motifs contain the beautiful aspects, of which in social communication often regarded as the irreplaceable ancient beauty [13]. Weaving motifs showcased the beauty in to their designs and colors which are usually dominated by the darker and bright colors [4]. All of the weaving motifs are indeed diverse between each disrict in Tanimbar. Having said that, each district has their own unique characteristic which are drawn in to weaving's motifs. Many of these motifs however, tell the different stories of the weaving women of Tanimbar. Their life's philosophy about nature and social interactions sometimes played out as their source of inspiration during their weaving creation process. Indeed, this type of creativity has its dynamic development from time to time.

Women's ability to play as the central role in the weaving can be argued as their way to express their value of autonomous energy.The complexity of imaginations and creativity of the women of Tanimbar, have inspired the designing process. Thus, weaving activities are an irreplaceable heritage of Tanimbar as well as for Indonesia. Further, the question arise in this study is how does these women designed the weaving's motifs based on their relation with the nature, society and local customs? In addition,to what extend do these weaving's motifs described the women's self perception within the patriarchal system of the Tanimbar society?

\section{Methodology}

The methodology used in this study is descriptive qualitatif methode, which aims to describe the systematic facts and characteristic of the samples. Also,by applling the literature and documentation to further explore the correlation between the different weaving motifs womens's inTanimbar. Further this methode will be of used to give thoroughly analysis towards the weaving women's perception during the designing and production process of the weaving motifs.

\section{Result and Discussion}

\section{The Motifs of Tenun Ikat Tanimbar}

Tanimbar island is one of the outer islands of Indonesia. Located in the southern part of Maluku, Tanimbar bridged and connects the Kei-Aru island and the Papua-Babar-Sermata island all through the Timor and Nusa Tenggara island[15]. Rich in unique and valuable customs and traditions, each districts in the islands have their own weaving motifs, which strongly suggests as the reflections of their local traditions, knowledge and beliefs [5].

Tenun Ikat Tanimbar has become the local wisdom, which were inherited from their ancestor have become the unique identity of the locals. Therefore, they showed the as the means of empowerment which represent the wisdoms and values of the society, both symbolically and the social interactions in their communities [14]. In this sense, this traditional values have placed women at the higher status of the society, and women are indeed seen as the symbol of peace-maker of the community. Women have received the highest appreciations in the society that can be identified as the ones that brings calmness, peace [14], as well as the symbol of fertility [4]. All of these identifiable values of women were undoubtedly shown and manifested through the many varieties of their weaving motifs. Tenun Ikat motifs clearly are the illustrations of the local wisdom which appreciate the fertility role and social status of women in Tanimbar.[4]

West Maluku Tenggara (Maluku Tenggara Barat) known for its richness and extensive source of weavings which are spread throughout the Tanimbar islands. And as mentioned before, different parts of the islands has their own uniqueness. West Maluku Tenggara Regency consists of 4 bigger islands of Yamdena, Selaru Island, Sulausa Island, and Fordata Island, as well as smaller group of islands. The weaving activities which are dominantly done by women are spread out in 10 different districts of the West Maluku Tenggara Regency, namely: South Tanimbar, Wertamrian, Kormomolin, Selaru, Wermaktian, Nirunmas, district of North Tanimbar, Yaru, Wuarlabobar, and Molumaru district. According the West Maluku Tenggara Bureau of Statistics [2] there are about 2.931 tenun ikat weavers who worked in the small business level, and these women weavers are also become the member of 206 weaving groups in each of the districts. Except for the district of Wermaktian, currently has no weaving groups, and the number of women weavers - 19 women, are the lowest compared to the other 9 districts. In general, these groups of women weavers are group and accommodated by the koperasi (unions). Meanwhile, in order to enhance the productivity of these women weavers and their groups, the municipality of the West Maluku Tenggara regency is currently doing the empowerment programs which aim to stimulate their working productivity to further fulfill the market's demand and also to create new opportunity for new markets. Different ways have been done by the local municipality, one of which were exhibitions to promote tenun ikat Tanimbar for both national and international markets.

There are approximately 47 Tanimbar weaving motifs that are somewhat related and meaningful to life[13]. Traditional weaving motifs have the important significance as the markers of family or cultural affiliation, and tend to be transmitted conservatively [3] and linearly bounded [12]. This means that women have managed to transferred 
their weaving skills to their daughters as well as to the daughters of their brothers, which were usually done inside the kinship communities [14] [4], especially in regard to the most complicated fabrics which carried on the important social functions, or often referred to as traditional fabrics [12]. Tanimbar women transfer their weaving skills to their daughters, but in fact, not all children could master these skills, thus, usually not all girls in one family can master it. Weaving is believed as the mandate from God which means that if someone is given the skills to weave, then it is an absolute abstinence to give it out to another person, and if this sort of rule is violated, then it is considered unable to carry out the mandate properly.

It has been known for some time that the weaving work has been internalized into the life of the Tanimbar community in general, and has been integrated into the culture and is embedded in the life of the Tanimbar community where women functioned as the weavers, which has regarded as a high position inside the social class of the Tanimbar community [14]. Various motives were then created from the self-concept of women, namely the women weavers; how women had perceived themselves during their interactions with the surrounding environments, with nature and also with each others. The contributions of women are quite highly appreciated in addition to producing Tenun Ikat Tanimbar. More to that, looking further into the design of motifs which are the results of the fact that women are conceptualizing themselves as women who have the domestic roles of their households, as well as women's perceptions of each other and the surrounding environments.

Various motives were then inspired by the women's self-concepts, namely weavers, how women perceive themselves in interacting with their surroundings, interacting with each other even with the customs that had been rooted in the Tanimbar community. Around 47 tenun ikat Tanimbar motifs that are known to, are still exist today. For the purpose of this study, I will only refer to the philosophical motives for the existence of women inside the Tanimbar community, and how their relations with the natural surroundings. All of these motifs are scattered around the various islands in the West Maluku Tenggara Regency [13]. The two islands that are known in producing the tenun ikat Tanimbar are the Yamdena island and Fordata island, which have several variety of Tenun Ikat Tanimbar motifs.

Yamdena Island has Tais Matan motifs, Tais Anday motifs, Maran motifs, Ulerati motifs, Lelumuku motifs, Sair motifs, Tunis motifs, Tul Saryar motifs, Sairar Lolohisi motifs and Sculptures, Sife Kikyeu motifs, and Manik motifs. While several motifs of tenun ikat fabrics were also found from Fordata Island, including Eman Mata Lihir motif, Eman Matan Tinemun motif, Matantur motif, Inelak Ian Natbunan motif, Wulan Lihir motif, Sair motif, Luhun Walun motif, and the Lakbuka motif.

The Tais Matan motif has the main design motif placed at the end of the fabric, while the remaining designs are somehow in reversed to the stripe lines motif of Tais Andang which has the black and white patterns on the edge of the fabric while the main motif is usually placed in the centre of the fabric. Meanwhile, the Maran motif is identified by the design of lines which are placed in the middle, while the main motif is at the tip of the foot. The Ulerati motif on the other hand, has a distinctive pattern of small caterpillars which accentuates the main parts of the weaving combined with several other motifs. The Ulerati motifs clearly denotes the philosophy for the love of the environment in which they lived in, as such, this motifs have shown their consideration about the life of the animals that they should preserved.

The Lelumuku motifs, which can be translated as orchids, are produced in almost throughout the Tanimbar islands. The characteristic of these motif is in the form of white orchids as the focus of the design. The philosophical concerns of this particular design is about women's beauty, grandeur and tenacity. The Sair motif or translated as the flag, tells story about the victory, independence, success and glory. The philosophy behind this motif is to illustrate that fact that the Tanimbar people are always eager to pursue life and maintain their identity in order to defend all women.

Further, the Tunis motif displayed the form of a single arrow or twin arrows, which illustrates the philosophy of the alertness or the cautiousness of the Tanimbar community in responding to all threats. This motif also represents the strength and mental readiness, also describing the habits of the Tanimbar people who are known for their hunting skills. The Tul Saryar motif is widely used to serve the purpose of traditional events, government-related events and the ecclesiastical occasions. For the motifs of the Lolohisi- Sair and the Statue of Lolohisi (patung Lolohisi), the design of designed of the centipedes, the flag and the statues are weaved together in a woven fabric, of which represents the philosophical value of their mutual cooperations in life. Almost as similar as the Tul Saryar motif, this motif also appeared in several events and celebrations of traditional events, government events and religiousrelated events. In the motif of Sife Kikyeu illustrates the pattern of a rooster, which is aligned with the Tanimbar society's traditional belief which tells the symbolic meaning that a rooster is often described to push away the evil spirits which may disturb the harmony of their life.

Another type of motifs, the Manik motif accentuates the design of pigeons which symbolize the luck, joy and affection. This motif also was inspired by the role of pigeons as the messenger and/or carrier of the news. 
Meanwhile in the island of Fordata, the single-eyed pattern and the motif of Eman Matan Tinemun which accentuates the so-called loincloths eyes, illustrates the role of women who are indeed have the responsibility in providing clothing, food and shelter for family's needs. In another motif such as the Matantur motifs, which provide the illustrations of the fish-bone motifs, almost has the similarity with the Ian Natbunan motif of which the salty fish patterns and weaved on the blue fabrics as its characteristics. Clearly, the Natbunan motif are the descriptions of the color of the sea surrounding their living area, is decorated with fish bone motifs that are arranged regularly and relate to one another. Both of these motifs have a philosophical wealth of marine resources that are vast and beautiful and have abundant results.

Lakbuka or Lizard / forest lizard motif is one of the weaving motif which is inspired by the one type of animal that lives in the forest and is often found by the Tanimbar people. The crescent which is particularly seen on the Wulan Lihir motif, illustrates the high ability of the Tanimbar people to interpret the natural signs around them. In their belief, for every crescent that appears, it provides them with a sign for the Tanimbar people to look for sea and land products. Lastly, the Luhun Walun motif or the dimpled face, is believed het its inspiration out of one of the kitchen utensils used to process food. This particular motif underlined the philosophical meaning concerning the efforts to achieve happiness that requires hard works based on sincerity.

Weaving has the closer association with the social, economic, religious, aesthetic aspects and moreover aspects of local customs [7]. Each of the woven fabric can also be used as a symbol that strengthens the social relations. The utilization of these weaving however, is conventionally served to cover parts of the body, but more to that has developed to complement the various traditional ceremonies ranging from birth, death, house making and even marriage.

\section{Women's Identity and Personal Perception}

Certainly, the development of a value of local wisdom, in this case weaving changes from time to time without diminishing its original identity. Identity is symbolic, open, political and dynamic [1]. As Asian textiles carry images and symbols which have transformed from time to time by faith, travel stories, long-distance trade, the trends of fashion and interiors, and through the rise and fall of power of the empires or country [16]. As in the Ottoman empire, in order to increase the power of the emperor, certain things needed to be done through constructing the motifs that were then translated into a variety of its local culture products such as court costumes, carpets and textiles, and even more into other media such as ceramic tiles, wood and precious metals. Similar to this, is what the Brunei Darusalam has done [18] of which the government played the active role in order to create their traditions, thus to revive national culture as a national identity, because without the human culture it would lose its identity as a social society [11].

From the various styles of the Tenun Ikat Tanimbar motifs and their philosophical meanings, reflect the priceless cultural richness. Some of the motives as mentioned before, embodied the philosophical aspects on the role of women in their daily lives as part of the Tanimbar community. This is reflected in the Lelumuku motif, the Sair motif, the Eman Matan Lihir motif, and the Eman Matan Tinemun motif. These motifs have reflected the women's perceptions in positioning themselves as part of the cultural identity as outlined in the Tenun Ikat Tanimbar motifs. Another uniqueness of the Tenun Ikat Tanimbar if compared to batik and several other types of weaving is the fact that the Tenun Ikat Tanimbar can be used by anyone regardless of their position or social status in the community. Arguably, this particularity is related to the kinship system of the Tanimbar community called 'Lebit Lokat' or 'Gold for All', which means that each individual has equal rights and obligations [4].

As a hereditary cultural inheritance, Tanimbar's weavings underlined the characteristic and strength of the local indigenous people. Certainly, the weavings have certain values and meanings both symbolically and socially for the Tanimbar community [14] where they place women in high social status. Women are considered as the peacemakers in their communities. Particularly, the weaving activities served as the high appreciation of the Tanimbar women, acknowledging women with serenity and peace [14] also fertility [4]. All of this acknowledgement and appreciation for women are indeed manifested through the variety of Tenun Ikat Tanimbar motifs which were always conveyed the high local wisdoms and values in regard to fertility and status of Tanimbar women [4].

As traditional women who live in a patriarchal environment, this circumstance has not decreasing their creativity to keep on preserving their ancestral heritage through weaving. The preservative power of sustainability is formed by the means of preserving the ability of women to recognize their existence towards others and their environment. With their limited knowledge however, the Tanimbar women have been trying out to carve in into the production of weaving fabrics which are full of meaning. Eventually, the inner strength to perceive themselves as women who are have the responsibility for preserving their ancestral heritage clearly displayed throughout the motifs they have created and carried out the sense of high value of art. 
Through this initial study, the researcher tries to describe the frame of mind in order to be able to know what is behind the making or design of Tenun Ikat Tanimbar motifs. For that reason, arguably these motives reflected the perception of a woman in the relation with the natural surroundings and to each other. In the initial observations, the Tanimbar women have strength from within themselves, therefore they are able to conceptualize or perceive themselves as outlined through the beautiful motifs of Tenun Ikat Tanimbar that can be identified and represented as an identity of their culture. The various motives that are already owned are usually related to community knowledge, culture and beliefs owned by the local community [5] or are there other factors that distinguish them such as beliefs that are believed by the local community as part of local wisdom, knowledge of the Tanimbar community, local culture, and the social system. For more details, it can be seen in the thinking framework below.

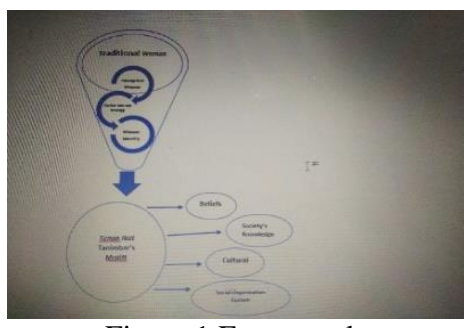

Figure 1 Framework

\section{Conclusion}

The patriarchal system is deeply rooted in the culture in the West Maluku Tenggara, and in the context of patriarchal culture women are indeed positioned as the subordinate of men. The initial assumption of this study suggests that women do not, or have not yet received the adequate opportunities to express themselves, even though they are considered as the peace makers. As a traditional woman who lives in a patriarchal culture, women are aware of the limited opportunities order to showcase their existence. But through the existence of Tenun Ikat Tanimbar, the variety in the motifs have suggested the women creativity expression and appreciation towards their inherited philosophical values. Through this initial research, the study tries to describe it through a framework of thinking so that they can map anything that lies behind women's perceptions in the designing process, also in the making process of the Tenun Ikat Tanimbar.

\section{Reference}

[1] Balesteros, Esteban Ruiz; Macarena Macarena Herna' ndez Ramı'rez. 2007. Identity and community:Reflections on the development of mining heritage tourism in Southern Spain. Tourism Management.

[2] BPS Kabupaten Maluku Tenggara Barat.2018. Kabupaten Maluku Tenggara Barat Dalam Angka.

[3] Buckley, Chrisopher D. 2012. Investigating Cultural Evolution Using Phylogenetic Analysis: The Origins and Descent of the Southeast Asian Tradition of Warp Ikat Weaving.

[4] de Jonge,Nico \& Van Dijk, Toos. 1995. Forgotten Islands of Indonesia. The Art \& Culture of the Southeast Moluccas.

[5] Directory of General National Export Development, Ministry of Trade of The Republic of Indonesia.2016.

[6] Esa, Ahmad \& Jamil, Nurul Isyraf Abd. 2013. Perception of Women as a Leader in The Tecnical and Vocational Education Field. Educational Technology.

[7] Gratha, Benny \& Achjadi, Judi. 2016. Tradisi Tenun Ikat Nusantara. Baba Publishing Indonesia.

[8] Hermayanti \& Erawati. 2016. Wanita Perajin Tenun Tradisional Di Nagarai Halaban, Kecamatan Lareh Sago Halaban Kabupaten Lima Puluh Kota, Sumatera Barat.

[9] Jones, C. (2012). Women's access to higher education. Herstoria Magazine, 2(2), page. 2-3.

[10] Kusumo, Rani Andriani Busi, Euis Sunarti, Diah K. Pranadji, 2008. Jurnal Kependudukan Padjajaran.Vol 10.

[11] Laurens, Theresa, Darma Ngilawayan1, Johan Pattiasina. 2014. Ethnomathematics Study of Islands Indigenous Peoples in Maluku Province, Indonesia.

[12] Lewis, ED. 1994. Chapter 7: Sikka regency. In Hamilton RW, editor (1994) Gift of the cotton maiden: textiles from Flores and the Solor Islands. University of California.

[13] Maniharapon, Grelinsia; H.Dektisa, Andrian; Ariani, Dian Bernadette. Perancangan Fashion Kain TEnun Ikat Kepuauan Tanimbar dan Media Pendukungnya.

[14] Maswekan, Max; Tahitu, Amelia; Freedom, Nanuru,Ricardo Freedom.2018. Symbolic and Socio-Cultural Meaning Tanimbar Woven Fabric. Advance in Social Science, Education and Humanities Research ( ASSEHR), vol.187. 
[15] Ririmase, Marlon. 2016. Arkeologi Kepulauan Tanimbar Bagian Utara: Tinjauan Potensi Di Pulau Fordata dan Pulau Larat Maluku Indonesia. Kapata Arkeologi, 12(1), 43-58.

[16] Scollay. Susan.2014. Translating Textiles: Poetry,profit and politics in the Imagery of he Woven Art of Asia. TASSA REVIEW VOL 23 NO. 3 SEPTEMBER.

[17] Sopamena, Junianita Fridianova \& Pattiselano, August Ernst. 2017. Tnyafar: Women, Livelihoods Strategy in Selaru Island, West Southeast Maluku District. International Journal of Environment, Agriculture and Biotechnology (IJEAB).

[18] Wahsalfelah, Siti Norkhalbi Haji. 2005. Invention of Traditions: Re-construction of Nation Identity through Traditional Textile in Brunei Darusalam.

[19] Zapasnik, Jonathon \& Hogan, Alexandra. 2015. Woman and Textile Manufacture in Clasical Athena, This text is taken from The ANU Undergraduate Research Journal, Volume Six, 2014. ANU eView, The Australian National University, Canberra, Australia. 